\title{
The Effects of Maternal Low Protein and Estrogen on Sexual Behavior and Testicular Maturation in Male Rats
}

\author{
Efectos de Niveles Maternos Bajos de Estrógeno y Proteína sobre el \\ Comportamiento Sexual y Maduración Testicular en Ratas Macho
}

Kavak, V.*; Balsak, D.**; Togrul, C.**; Deveci, E.***; Ekinci, A.***, Ekinci, C.** \& Babacan, F.*****

KAVAK, V.; BALSAK, D.; TOGRUL, C.; DEVECI, E.; EKINCI, A.; EKINCI, C. \& BABACAN, F. The effects of maternal low protein and estrogen on sexual behavior and testicular maturation in male rats. Int. J. Morphol., 33(1):204-209, 2015.

SUMMARY: In recent years, disorders related to the development and function of the male reproductive tract has increased, thus generating a surprising decrease in semen volume and sperm count. We examined the effects of low protein and estrogen on sexual behavior and testicular maturation in male rats. We also examined FSH, LH and testosterone levels and histological damage of testis tissue. The male rats were subjected to standard long-term treatment with estradiol by oral and paranteral delivery. The number of mounts, copulatory efficiency and ejaculation latencies for the paranteral protein diet (PPD) group was significantly lower than those in a group nourished with a low protein diet (LPD) and oral protein diet (OPD) groups $(\mathrm{P}<0.05)$. Testes and epididymis sections were examined by four grades, according to the level of damage of epithelium in the testes and epididymis. Higher histological damage was also detected in the PPD group. In conclusion, the present study confirmed that unwanted estrogen effects were higher in the paranteral administered group on examination of sexual behavior and histological damage of epithelium in the testes and epididymis of male rats.

KEY WORDS: Estrogen; Low protein; Sexual behavior; Histological damage.

\section{INTRODUCTION}

In recent years, disorders related to the development and function of the male reproductive tract has increased, thus generating a surprising decrease in semen volume and sperm count. This may be due to an increase in exposure to estrogen (E) at different stages of fetal or neonatal development (Vigueras-Villasenor et al., 2006). In agreement with the notion that estrogen exposure during development may impair male fertility, it has been known for many years that estrogen administration to experimental animals during the neonatal period or adulthood can impair sperm production and maturation (O'Donnell et al., 2001). The role of estrogen in male reproduction remains unclear, although it is known that $17 \mathrm{~b}$ estradiol is present at high concentrations in the testicular fluid and receptors for estrogen are widely distributed in the male reproductive tract of various species, including rats (Sharpe et al., 1995; Sharpe, 2003; Eddy et al., 1996; Atanassova et al., 1999, 2000; Goyal et al., 2003, 2004).
Under nutrition is known to have a wide variety of effects on endocrine systems. Regarding the reproductive system, it has been shown that food restriction can inhibit both the maintenance and onset of reproductive capability. In adult rats, food restriction can reduce weight as well as testes, epididymis, and prostate weights. The serum concentration of LH, FSH and testosterone are also reduced by undernutrition. Malnutrition has been shown to lead to morphological gonadotrophic alterations that are typical of those found in cells whose secretory activities are suppressed. Low protein treatments showed that early undernutrition produced sexual behaviour dysfunction in male rats (Howland, 1975; Fernandez et al., 1997; Young et al., 2000; Santos et al., 2004).

In this study, we examined the effects of low protein and estrogen on sexual behavior and testicular maturation of male rats. We also examined FSH, LH and testosterone levels and histological damage of epithelium in the testes and epididymis.

* Department of Anatomy, Faculty of Medicine, University of Dicle, Diyarbakır, Turkey.

** Department of Obstetrics and Gynecology Diyarbakır Maternity and Children Hospital, Diyarbakir, Turkey.

*** Department of Histology and Embryology, Faculty of Medicine, University of Dicle, Diyarbakir, Turkey.

***** Department of Biochemistry, Faculty of Medicine, University of Dicle, Diyarbakir, Turkey.

***** Department of Obstetrics and Gynecology, Venividi of Hospital, Diyarbakir, Turkey. 


\section{MATERIAL AND METHOD}

Animals. Timed Pregnant Wistar rats were obtained from Research and Applied Health Center of Dicle University. All animal procedures were approved by the Ethics Committee of Experimental Animals of Dicle University and were kept in a room with controlled temperature $\left(25 \pm 1^{\circ} \mathrm{C}\right)$ and artificial light-dark cycles (lights on from 07:00 am to 07:00 pm).

In this study, 30 male Wistar rats born from the pregnant rats were used. Rats $(n=10)$ were subjected to preand postnatal undernutrition by restricting the food intake of their mothers; the other group of rats was normally fed. The normal nutrition group was divided into two subgroups administered orally $(n=10)$ and parenterally $(n=10)$ with estrogen. They administered estrogen from 45 days untill 55 days; the male rats were subjected to standard long-term treatment with estradiol.

We fed the post-weaning male rats with the same diet as their mothers after the weaning time until adulthood. The first group was nourished with maternal low protein diet (including $4 \%$ protein) (LPD). The second group was nourished with Normal Protein Diet (including $24 \%$ protein) (OPD) and were orally administered $1 \mu \mathrm{g}$ of 17 -b-estradiol from postweaning to adult. The third group was nourished with Normal Protein Diet (including 24\% protein) (PPD) and was intraperitoneal administered $1 \mu \mathrm{g}$ of 17-b-estradiol dissolved in corn oil daily from post-weaning to adulthood. All postweaning male rats were evaluated; in terms of their nutritional state, food consumption and body weight were monitored throughout the experiment. During this period, sexual behavior was analyzed three times, at an interval of seven days between each test. The males' sexual behavior was studied in interaction tests with an intact female. It was evaluated according to a scale of sexual responsiveness.

At the end of the experiment, all animals were anesthetized via the intraperitoneal administration of ketamine HCL $(0.15 \mathrm{ml} / 100$ g body weight). The blood was collected by cardiac puncture, and serum was stored at $-20^{\circ} \mathrm{C}$. Blood samples were obtained before killing for serum albumin determination (Roche Diagnostic GmbHD-68298 Mannheim, USA: Roche Diagnostics, Indianapolis, IN). Serum testosterone, FSH and $\mathrm{LH}$ levels were determined by electrochemiluminescent immunoassay (ECLIA) with Modular E 170 Roche autoanalyzer. A midline abdominal incision was performed in all of the rats. The testis and epididymis were excised, dissected, weighted, and stored at $-70^{\circ} \mathrm{C}$. Testes and epididymis were carefully removed, fixed in formaldehyde, embedded in paraffin, cut following the longitudinal axis, and stained with hematoxylin-eosin. These sections were examined under a light microscope by a histologist. Epididymis and testis sections were graded by 4-level grading scales (GonzalezReimers et al., 1994). The following parameters were recorded: Grade 1 showed normal testicular architecture with an orderly arrangement of germinal cells; Grade 2 injury showed less orderly non-cohesive germinal cells and closely packed seminiferous tubules; Grade 3 injury exhibited disordered sloughed germinal cells with shrunken pyknotic nuclei and less distinct seminiferous tubule borders; Grade 4 injury defined seminiferous tubules that were closely packed with coagulative necrosis of the germinal cells.

Treatments. The two treatments in this study were an isocaloric CPD, consisting of $24 \%$ protein, and an experimental LPD of $4 \%$ protein. Two treatments were based on the AIN93G standard diet recommended to support growth (Reeves et al., 1993). Two treatments (Dyets, Bethlehem, PA) were isocaloric; thus the only dietary variable altered was protein (Table I). Food consumption and spillage were measured to the nearest $0.1 \mathrm{~g}$, using a Tefal Scientific Model Gourmet 7986502/261-0304 electronic scale. Pregnant rats were monitored carefully so that the exact date of birth could be known. The new-born rats were held at the same place with their mother until post-weaning. At puberty, all post-weaning rats were separated by sex and randomly assigned to one of the two treatments. The post-weaning rats were weaned at 22 $\mathrm{d}$ of age, placed in hanging basket cages and allowed to eat and drink ad libitum. Each rat was housed in a separate cage so that food consumption and body weight could be measured daily. Body weight was also measured to the nearest gram using the same electronic scale Tefal (France). Daily weighing ensured and provided data for subsequent analysis.

\begin{tabular}{lcc} 
Table I. Contents of low protein (LPD) and control (NPD) protein treatments. \\
\hline Ingredient (g/kg) & $\begin{array}{c}\text { Low (LPD) } \\
\text { (4\% protein) diet }\end{array}$ & $\begin{array}{c}\text { Normal (NPD) } \\
\text { (24\% protein) diet }\end{array}$ \\
\hline Casein & 46.00 & 276.00 \\
Cornstarch & 500.90 & 329.90 \\
Dyetrose & 167.00 & 110.00 \\
Sucrose & 100.00 & 100.00 \\
Cellulose & 50.00 & 50.00 \\
Soybean oil & 70.00 & 70.00 \\
t-Butylhydroquinone & 0.014 & 0.014 \\
Salt mix\#213266 & 35.00 & 35.00 \\
Calcium phosphate dibasic & 11.66 & 4.08 \\
Calcium carbonate & 3.91 & 9.49 \\
Vitamin mix\#310025 & 10.00 & 10.00 \\
L-Cystine & 0.700 & 4.10 \\
Choline bitartrate & 2.50 & 2.50 \\
Blue dye & --- & 0.050 \\
\hline
\end{tabular}


Sexual behavior. Each study group male rat was tested for sexual capability three times, at an interval of seven days between each test. Sexual behavior observations were performed at 04:00 am and 07:00 am using infrared ligh in the cycle. Male rats were placed in a standard cage $(60 \mathrm{~cm} \mathrm{x}$ $60 \mathrm{~cm} \times 100 \mathrm{~cm}$ ). A sexually receptive female rat was introduced in the cage and the matting test started after the male rats were adapted to the cage. The following measures were recorded or calculated: ejaculatory latency, the number of mounts without intromission prior to ejaculation; copulatory efficiency, and a measure of intermissive success (calculated as percentage of mounts in which the male gained vaginal insertion). Each test was recorded using a Sony (DCRA-C150 model, handycam station, 3.0 Mega Pixels) digital camera, and scored subsequently by using a computerized event recorder customized for male sexual behavior.

Statistical analysis. Means and standard deviations (SD) for continuous and median values for discrete variables were calculated. Categorical data were evaluated by the Kruskal Wallis test for three groups, and Mann Whitney test for two groups. $\mathrm{P}$ values were considered statistically significant at $\mathrm{P}<0.05$. Statistical analyses were carried out using the statistical packages for SPSS 15.0 for Windows (SPSS Inc., Chicago, IL, USA).

\section{RESULTS}

Changes in serum hormone levels. Alterations in testosterone, FSH, and LH levels are shown in Table II. The mean values of serum FSH, and LH were not found to be significant for the three groups $(\mathrm{P}>0.05)$. The mean values of serum testosterone levels were found to be significantly different between LPD - OPD, and OPD-PPD groups $(\mathrm{P}<0.05)$. However, there was not any difference between the mean values of LPD and PPD $(\mathrm{P}<0.832)$.

Weight changes. The mean final body and testis weight $( \pm \mathrm{SD})$ at 80 days of age in male rats of the three groups (LPD, OPD, and PPD) were found to be significantly different $(\mathrm{P}<0.001)$ when the results of Table II were examined.

Sexual behaviour. The mean frequencies of mount number and copulatory efficiency for the three groups are presented in Figures 1, 2 and 3. The numbers of mount, copulatory efficiency and ejaculation latencies for the PPD group were significantly lower from those in the LPD and OPD groups $(\mathrm{P}<0.05)$, and LPD was lower than OPD, when compared with each other $(\mathrm{P}<0.05)$.

Table II. Characteristics of the variables.

\begin{tabular}{lcccc}
\hline Variables & $\begin{array}{c}\text { LPD } \\
\mathbf{n = 1 0}\end{array}$ & $\begin{array}{c}\text { OPD } \\
\mathbf{n = 1 0}\end{array}$ & $\begin{array}{c}\text { PPD } \\
\mathbf{n = 1 0}\end{array}$ & $\mathbf{p}$ \\
\hline Body weight $(\mathrm{g})$ & $37.5 \pm 4$ & $380 \pm 31$ & $378 \pm 34$ & $<0.0001$ \\
Testis weight $(\mathrm{mg})$ & $4.3 \pm 0.4$ & $14.7 \pm 3.5^{*}$ & $10.5 \pm 1.9$ & $<0.0001$ \\
FSH & $0.13 \pm 0.01$ & $0.13 \pm 0.02$ & $0.14 \pm 0.02$ & $=0.065$ \\
LH & $0.11 \pm 0.01$ & $0.10 \pm 0.01$ & $0.10 \pm 0.01$ & $=0.150$ \\
Testosterone & $0.735 \pm 0.301$ & $1.436 \pm 0.301$ & $0.592 \pm 0.223$ & $<0.0001$ \\
\hline
\end{tabular}

Testosterone (Group1-Group2): $\mathrm{P}=0.036$; Testosterone (Group1-Group3): $\mathrm{P}=0.832$; Testosterone (Group2-Group3): $\mathrm{P}=0.002$.

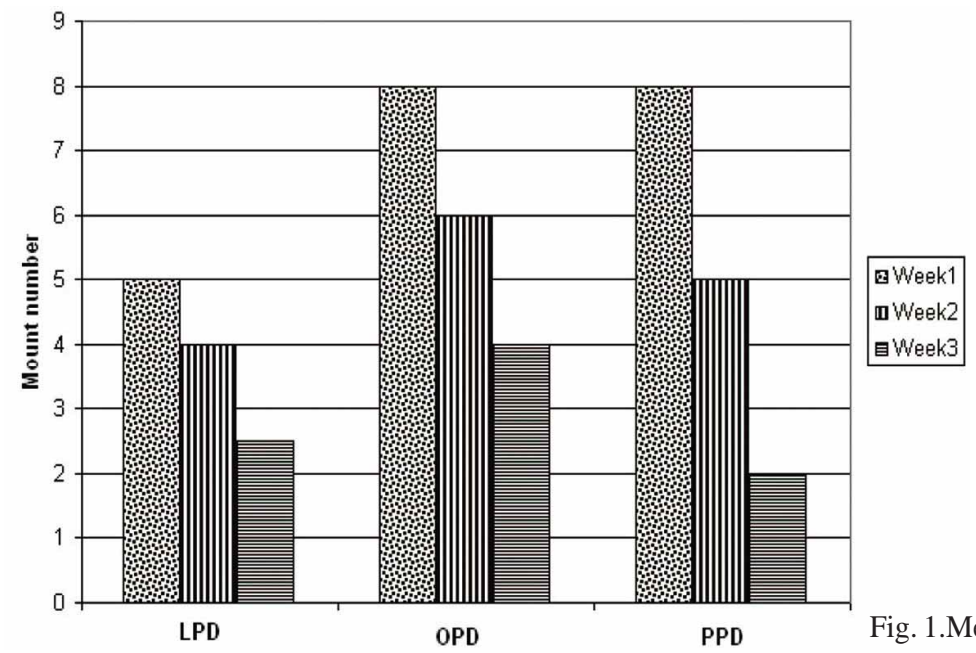

Fig. 1.Mean values of mount number of male rats in the three groups. 


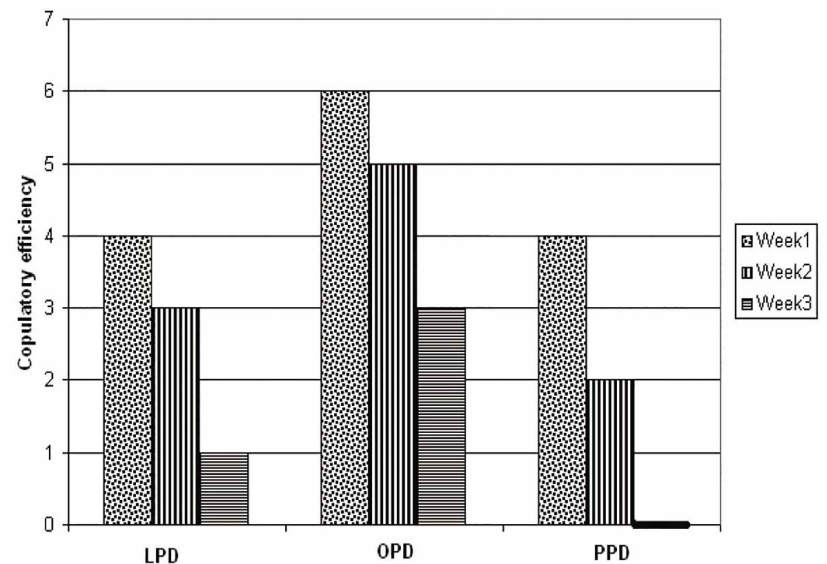

Fig. 2. Mean values of copulatory efficiency of male rats in the three groups.

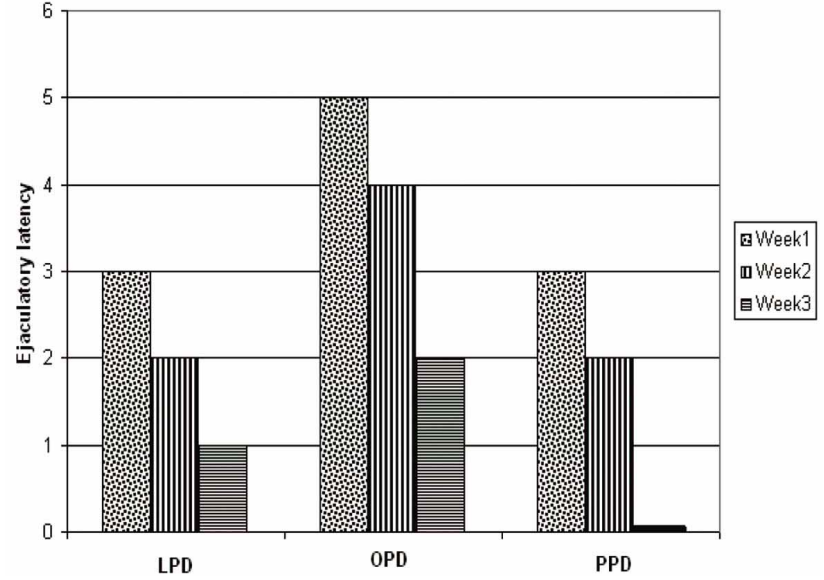

Fig. 3. Mean values of ejaculatory latency of male rats in the three groups.

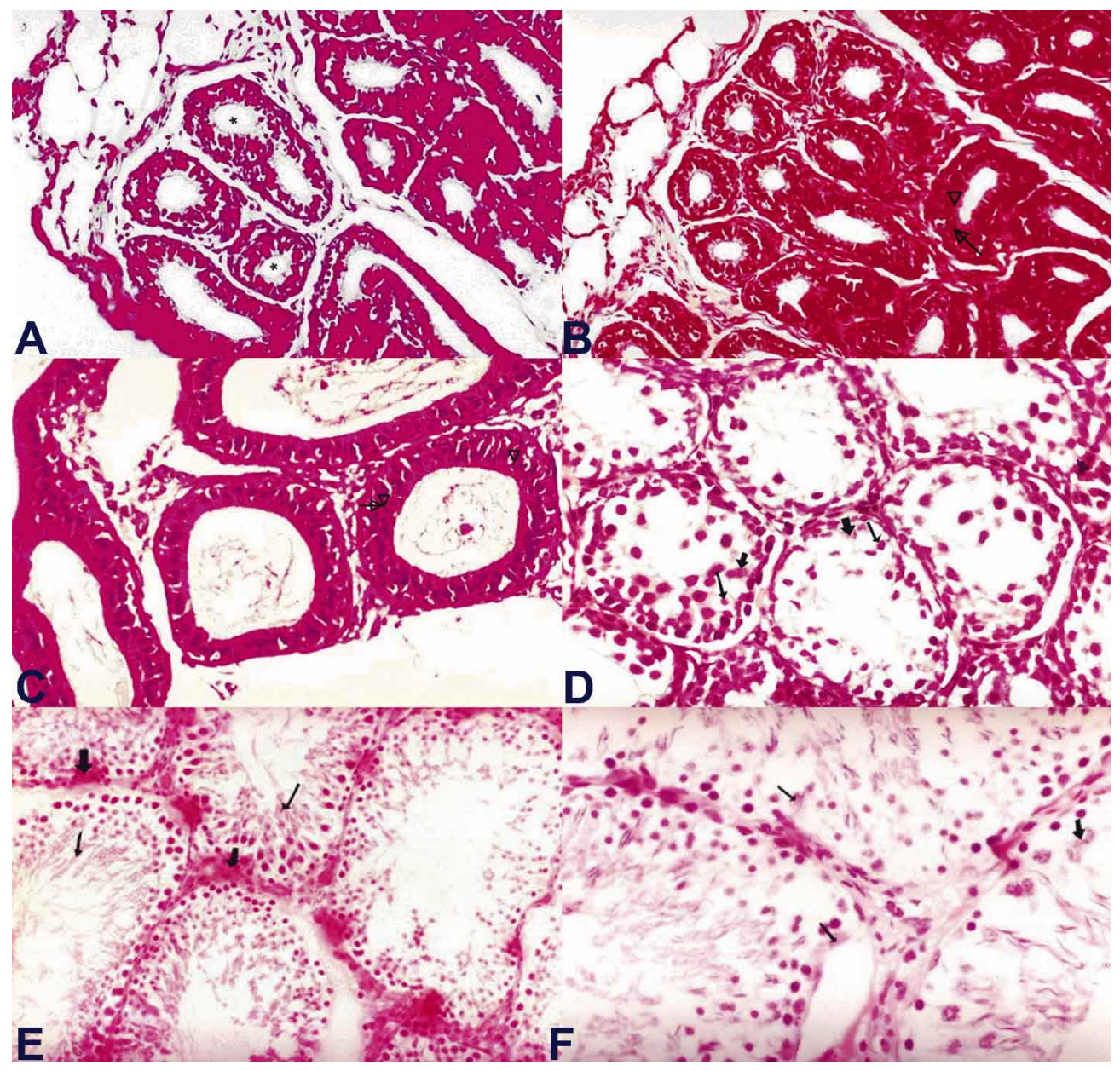

Fig. 4. Histologic sections (A, B, C, D, E, F) of epididymis and testes of male rats in the three groups. A. (PPD) Hyposperm in epididimy canal sections and mononuclear cell infiltration in tubular lumen (star) (Grade 2). Hematoxilen-eosin original magnification x82. B. (OPD) An increase in connective tissue in inter tubular area (arrow) Grade 3. Hematoxilen-eosin original magnification x82. C. (LPD) Atrophic and hypospermic cells in some tubular structure (arrow) (Grade 2.5). Hematoxilen-eosin original magnification $\mathrm{x} 82$. D. (PPD) A decrease in spermatic cells and degeneration in tubular structure (arrow) (Grade 4). Hematoxilen-eosin original magnification x82. E. (LPD) Spermatic cells in the tangelike shape (arrow) (Grade 2, Grade3). Hematoxilen-eosin original magnification $x 82$. F. (OPD) Hypospermatic cells in tubular structure (arrow) (Grade 3). Hematoxilen-eosin original magnification $\mathrm{x} 82$.
Histological changes. The level of damage of epithelium in the testes and epididymis were examined by four grades. The highest degeneration of abnormal cells was graded as Grade 4. The distribution of histological damage grades in three groups are shown in Table III and Figure 4. The mean values of epididymis $(\mathrm{X} 2=14.97, \mathrm{P}=0.001)$, and testes $(\mathrm{X} 2=14.97, \mathrm{P}<0.001)$ of the three groups were found to be significantly different. 
Table III. Grades of histological damage in the three groups.

\begin{tabular}{lcc}
\hline Groups & $\begin{array}{c}\text { Grade of } \\
\text { epididymis } \\
\text { Median }\end{array}$ & $\begin{array}{c}\text { Grade of } \\
\text { test es } \\
\text { Median }\end{array}$ \\
\hline LPD & 2 & 2.5 \\
OPD & 1 & 3 \\
PPD & 2.5 & 4 \\
Kruskal-Wallis Test $\mathrm{X}^{2}$ & 14.97 & 18.12 \\
P & $=0.001$ & $<0.0001$ \\
\hline
\end{tabular}

\section{DISCUSSION}

Estrogen has been shown to have a definitive role in spermatogenesis, but the molecular events directly regulated by it have remained enigmatic (D'Souza et al., 2005). It has been suggested that rats exposed to estrogen during the neonatal period show permanent damage in the adult male reproductive organs, such as a decrease in testicular weight (Vigueras-Villasenor et al.). It has also been demonstrated that estrogen has the capacity to have an impact upon male fertility of direct and indirect roles in the development and maintenance of reproductive function (O'Donnell et al.; Goyal et al., 2003, 2004). In the present study, we analyzed the adverse effect of estrogen administered during the neonatal stage. The present results confirmed earlier reports of infertility in male rats that received estrogen neonatally and were tested for fertility. Results in Table II shows that the body weight, testis weight, and testosterone levels were found significantly different $(\mathrm{P}<0.001)$; however, FSH and LH levels were not significantly different $(\mathrm{P}>0.05)$. The mean values of body weight, testis weight, and testosterone level $(378 \pm 34,10.5 \pm 1.90,0.592 \pm 0.22$ respectively) in the PPD group were found to be lower than those in the OPD group $(380 \pm 31,14.7 \pm 3.50,1.436 \pm 0.30$ respectively). Throughout the present study, newer findings are suggested in regards to the effects of oral estrogen administration. However, we observed that OPD was not affected by body weight, testis weight or testosterone level according to the PPD group. In the same way, as seen in the Figures 1, 2 and 3, the mount number, copulatory efficiency, and ejaculatory latency were found to be lower in the PPD group. We thought that the reason for poor performance observed for the PPD group was due to the body's defense system that protects against foreign invaders in the OPD group. The body's defense system is a complex integrated response with multiple components (Martin \& Dodds, 2006). The mean values of body weight and testis weight of the LPD group (37.50 $\pm 4,4.285 \pm 0.40$ respectively) were found to be lower than those of both the OPD and PPD groups; however, the mean testosterone level $(0.735 \pm 0.301)$ was lower only than that of the OPD group, but higher than the level of the PPD group. The low protein diet could not dramatically decrease testosterone level as it could for body weight and testis weight. According to our results, the lowest testosterone level was observed in the PPD group. Researchers suggest high intratesticular estradiol with a concomitant decrease in intratesticular testosterone levels on spermatogenesis (D'Souza et al.; Della Seta et al., 2006). The results of our study are consistent with those reported in these earlier studies.

One of the aims of this study was to test the effects of estrogen on sexual behaviour. At adulthood, the activation of male sexual behavior depends on testosterone circulating levels, its effects being mediated by androgen receptors in specific hypothalamic nuclei (McGinnis et al., 1996; Heart et al., 2004; D'Souza et al.). In the present experiment, we observed that $\mathrm{T}$ levels were reduced lower in adult male rats after the post-weaning period by the effect of estrogen administered paranterally (PPD group). It has been suggested that there are three reward pathways for male sexual behavior. The first involves the number of mounts, the second is copulatory efficiency and the third is ejaculation latencies (Afonso \& Pfaus, 2006). The results of Figures 1, 2 and 3 also show poor sexual performance in the PPD group. In order to support these findings, we analyzed the effects of estrogen in the damage of epithelium in the testes and epididymis by histological examination. Higher histological damage (maximum grade) was also detected in the PPD group as seen in Figure 4.

In conclusion, the present study confirmed that unwanted estrogen effects when paranterally administered were higher in the examination of sexual behaviour and histological damage of epithelium in testes and epididymis in male rats.

KAVAK, V.; BALSAK, D.; TOGRUL, C.; DEVECI, E.; EKINCI, A.; EKINCI, C. \& BABACAN, F. Efectos de niveles maternos bajos de estrógeno y proteína sobre el comportamiento sexual y maduración testicular en ratas macho. Int. J. Morphol., 33(1):204-209, 2015.

RESUMEN: En los últimos años, los trastornos relacionados con el desarrollo y la función del tracto reproductivo masculino han aumentado, lo que genera una disminución importante en el volumen de semen y el conteo de espermatozoides. Se examinaron los efectos de niveles bajos en proteínas y estrógeno en el comportamiento sexual y la maduración testicular en ratas macho. También se examinaron FSH, LH y los niveles de testosterona y el daño histológico de tejido testicular. Las ratas macho fueron sometidas al tratamiento y administración estándar a largo plazo con estradiol por vias oral y parenteral. El número de montajes, eficiencia de copulación y latencias de eyaculación para el grupo de dieta de proteínas parenteral (DPP) fue significativamente menor que los del grupo con una dieta baja en proteínas (PBD) y de proteína oral baja $(\mathrm{POB})$ grupos $(\mathrm{P}<0,05)$. Fueron examinados los testículos y epidídimo de acuerdo a cuatro grados, en relación al nivel de daño del epitelio en los testículos y 
epidídimo. También se detectó un mayor daño histológico en el grupo DPP. En conclusión, se confirma que los efectos no deseados del estrógeno fueron mayores en el grupo con administración parenteral en el examen de conducta sexual y en el daño histológico del epitelio en los testículos y el epidídimo de ratas macho.

PALABRAS CLAVE: Estrógeno; Baja proteína; Comportamiento sexual: Daño histológico.

\section{REFERENCES}

Afonso, V. M. \& Pfaus, J. G. Hormonal and experiential control of femalemale mounting in the female rat. Horm. Behav., 49(1):30-7, 2006.

Atanassova, N.; McKinnell, C.; Walker, M.; Turner, K. J.: Fisher, J. S.; Morley, M.; Millar, M. R; Groome, N. P. \& Sharpe, R. M. Permanent effects of neonatal estrogen exposure in rats on reproductive hormone levels, Sertoli cell number, and the efficiency of spermatogenesis in adulthood. Endocrinology, 140(11):5364-73, 1999.

Atanassova, N.; McKinnell, C.; Turner, K. J.; Walker, M.; Fisher, J. S.; Morley, M.; Millar, M. R.; Groome, N. P. \& Sharpe, R. M. Comparative effects of neonatal exposure of male rats to potent and weak (environmental) estrogens on spermatogenesis at puberty and the relationship to adult testis size and fertility: evidence for stimulatory effects of low estrogen levels. Endocrinology, 141(10):3898-907, 2000.

Della Seta, D.; Minder, I.; Belloni, V.; Aloisi, A. M.; Dessì-Fulgheri, F. \& Farabollini, F. Pubertal exposure to estrogenic chemicals affects behavior in juvenile and adult male rats. Horm. Behav., 50(2):3017, 2006.

D'Souza, R.; Gill-Sharm, M. K.; Pathak, S.; Kedia, N.; Kumar, R. \& Balasinor N. Effect of high intratesticular estrogen on the seminiferous epithelium in adult male rats. Mol. Cell. Endocrinol., 241(1-2):41-8, 2005.

Eddy, E. M.; Washburn, T. F.; Bunch, D. O.; Goulding, E. H.; Gladen, B. C.; Lubahn, D. B. \& Korach, K. S. Targeted disruption of the estrogen receptor gene in male mice causes alteration of spermatogenesis and infertility. Endocrinology, 137(11):4796-805, 1996.

Fernandez, S.; Gonzalez, C. \& Patterson, A. M. Oil enriched diets and behavioral parameters in rats' recovery from early undernutrition. Physiol. Behav., 62(1):113-9, 1997.

Gonzalez-Reimers, E.; Martinez-Riera, A.; Santolaria-Fernandez, F.; Conde-Martel, A.; Alvarez-Argüelles, H.; Santana-Herrera, C. \& Rodriguez-Moreno, F. Relative and combined effects of ethanol and protein deficiency on gonadal function and histology. Alcohol, 11(5):355-60, 1994.

Goyal, H. O.; Robateau, A.; Braden, T. D.; Williams, C. S.; Srivastava, K. K. \& Ali, K. Neonatal estrogen exposure of male rats alters reproductive functions at adulthood. Biol. Reprod., 68(6):2081-91, 2003.

Goyal, H. O.; Braden, T. D.; Williams, C. S.; Dalvi, P.; Williams, J. W. \&
Srivastava, K. K. Exposure of neonatal male rats to estrogen induces abnormal morphology of the penis and loss of fertility. Reprod. Toxicol., 18(2):265-74, 2004.

Heralth, C. B.; Jin, W.; Watanabe, G.; Arai, K.; Suzuki, A. K. \& Taya, K. Adverse effects of environmental toxicants, octylphenol and bisphenol A, on male reproductive functions in pubertal rats. Endocrine, 25(2):163-72, 2004.

Howland, B. E. The influence of feed restriction and subsequent re-feeding on gonadotrophin secretion and serum testosterone levels in male rats. J. Reprod. Fertil., 44(3):429-36, 1975.

Martin, N. \& Dodds, C. Protective mechanisms of the body. Anaesth. Intensive Care Med., 7(12):459-61, 2006.

McGinnis, M. Y.; Williams, G. W. \& Lumia, A. R. Inhibition of male sex behavior by androgen receptor blockade in preoptic area or hypothalamus, but not amygdala or septum. Physiol. Behav., 60(3):783-9, 1996.

O’Donnell, L.; Robertson, K. M.; Jones, M. E. \& Simpson, E. R. Estrogen and spermatogenesis. Endocr. Rev., 22(3):289-318, 2001.

Reeves, P. G.; Nielsen, F. H. \& Fahey, G. C. Jr. AIN-93 purified diets for laboratory rodents: final report of the American Institute of Nutrition ad hoc writing committee on the reformulation of the AIN-76A rodent diet. J. Nutr., 123(11):1939-51, 1993.

Santos, A. M.; Ferraz, M. R.; Teixeira, C. V.; Sampaio, F. J. \& da Fonte Ramos, C. Effects of undernutrition on serum and testicular testosterone levels and sexual function in adult rats. Horm. Metab. Res., 36(1):27-33, 2004.

Sharpe, R. M.; Fisher, J. S.; Millar, M. M.; Jobling, S. \& Sumpter, J. P. Gestational and lactational exposure of rats to xenoestrogens results in reduced testicular size and sperm production. Environ. Health Perspect., 103(12):1136-43, 1995.

Sharpe, R. M. The 'oestrogen hypothesis'- where do we stand now? Int. J. Androl., 26(1):2-15, 2003.

Vigueras-Villaseñor, R. M.; Moreno-Mendoza, N. A.; Reyes-Torres, G.; Molina-Ortiz, D.; León, M. C. \& Rojas-Castañeda, J. C. The effect of estrogen on testicular gonocyte maturation. Reprod. Toxicol., 22(3):513-20, 2006

Young, K. A.; Zikrin, B. R. \& Nelson, R. J. Testicular regression in response to food restriction and short photoperiod in white-footed mice (Peromyscus leucopus) is mediated by apoptosis. Biol. Reprod., 62(2):347-54, 2000.

\section{Corespondence to:}

Engin Deveci

Dicle University

Medical Faculty

Histology and Embryology

Dept. 21280 Diyarbakir

TURKEY

Received: 05-08-2014

Accepted: 15-11-2014

Email: engindeveci64@gmail.com 